\title{
ACTIVITY ON MALAY SQUARE'S OPEN SPACE AS A NODE OF TANJUNGPINANG CITY
}

\author{
Septy Karmawan \\ Dosen Tetap Prodi Teknik Arsitektur UNRIKA Batam
}

\subsection{Background}

\author{
CHAPTER I \\ INTRODUCTION
}

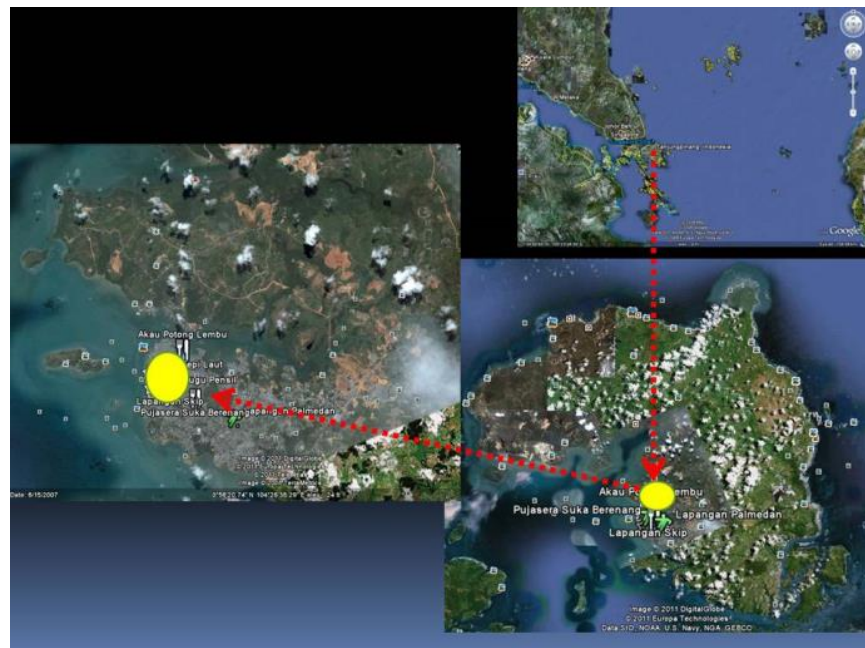

Picture, 1.1 : Site Location and Tanjungpinang City against Bintan island and neighboring countries

Source : Google Earth

Seaside is an open space as a public gathering place various kinds of activities whose existence was known by the City Community open space public seaside city tanjungpinang, because this is not only a place of gathering of all people from all over the city, where people meet people from various sorts of places in the area to do the activities they want in the open space while enjoying the ambiance as well as a lounge and night sights

\subsection{Problems Formulation}

1. activities that take place at a location has not yet been handled so that activities that are not yet running optimally.

2. Any other functions outside the main function in a specific facility amenities which causes crowdetness and inconvenience the situation.

3. Lay out of Public space Lay out has not been arranged so that it has not yet been optimal utilization of open spaces.

\section{3.the intent and purpose}

\subsubsection{The Intent}

Study of activity that occurred at a location site in order to be able to identify the activities of the open space needed.

\subsubsection{The Purpose}


Making recommendations open space as a container for the activities of representative which takes place in it.

\subsection{Research Questions}

1. Such of whether the characteristic of activity.

2. Such of whether the characteristic of public.

3. how the relationship between the activity in which there is an open space.

\section{CHAPTER II \\ Literature Review}

\subsection{Activity}

\subsubsection{Activity Meaning}

The word activities derived from a enterprising that in a dictionary bahasa online mean diligent ; passionate, and eager ( deed, venture ), while said own activities connote activity ( activity ), business work, strength and agility ( trying ), fervency . Of the foregoing then activity can be in define, the series behavior happened at certain times for reached one purpose.

\subsection{2. the type and variety of activities}

a. Necessary activity, regular activities are always performed by human beings.

$b$. Optional activity, yaitu activities that take place depending on the conditions.

\subsubsection{Activity pattern}

According to Ashihara in Aslim H, 1991, there are 2 activity patterns of human.

a. stay, These activities are conducted on a certain point area.

b. move, the subject move from one place to another.

\subsubsection{Activity Character}

According to Amos Rapoport, 1970, the main important thing to note on the interaction between the activities and activity in the environment are:
a. What and why that activity happened.
b. Who and what are the subject of activity.
c. What time of that activity happened.
d. Where is the activity happened.
e. How is the behavior of the activity.

\subsection{Open Space}

\subsubsection{The Meaning of Open Space}

According to Trancik, 1986, open space does not covered so there will be Intervention interaction and intersection. In other side, according to Hamid Shirvani, 1985, open space is a space which is not dominated by building.

\subsubsection{Edges of Open Space}

According to its character, Trancik, 1986 divide room into :

1. Soft edges.

2. Hard edges.

\subsubsection{Open Space forms}

According to Krier (1984) open space could be divided into 2 form :
a. Square
b. Street

\subsubsection{Open Space Characters}

According to its activity, open space could be divided into :

1. Active Open Space. 
2. Passive Open Space.

According to its ownership, open space could be divided into :

1. Private Open Space.

2. Public Open Space.

\subsubsection{Open Space Functions}

- Recreation, Rest and Relax place

- Social Contact

- Personal Creativity

- Nature Experience

- As a place for any transportation (car, bicycle)

\subsubsection{Element of Open Space}

According to Aristoteles in Cornelis Van Ven ,1995, The room is as a place of belonging or where that location where each element physical are. This theory, is that there are two part in a room that is currently framer and filler the open space.

\subsection{Theoretical}

Public space in seaside of Tanjungpinang is a public open space which is being a social place. According to Rapoport some of which must be observed in the relationship of activities and its surroundings :

a. What and why that activity happened.

b. Who and what are the subject of activity.

c. What time of that activity happened.

d. Where is the activity happened.

e. How is the behavior of the activity.

Arestoteles by Cornelis Van Ven open space element can be misconstrued consists of two major parts, namely Shaper and fillers.

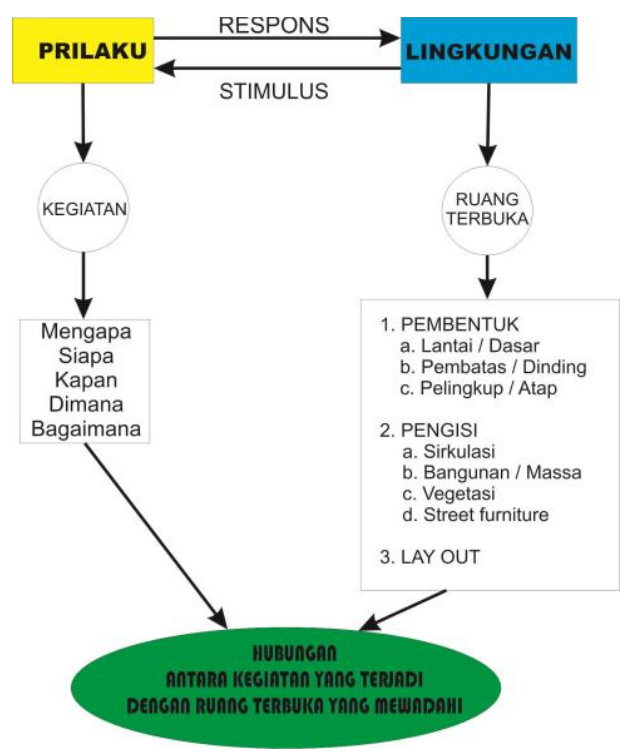

Chart, 2 - 1 : Groove theory framework research Source : Analyze 


\section{CHAPTER III \\ Research Method}

\subsection{LOCUS and FOCUS of the RESEARCH}

\subsubsection{Locus}

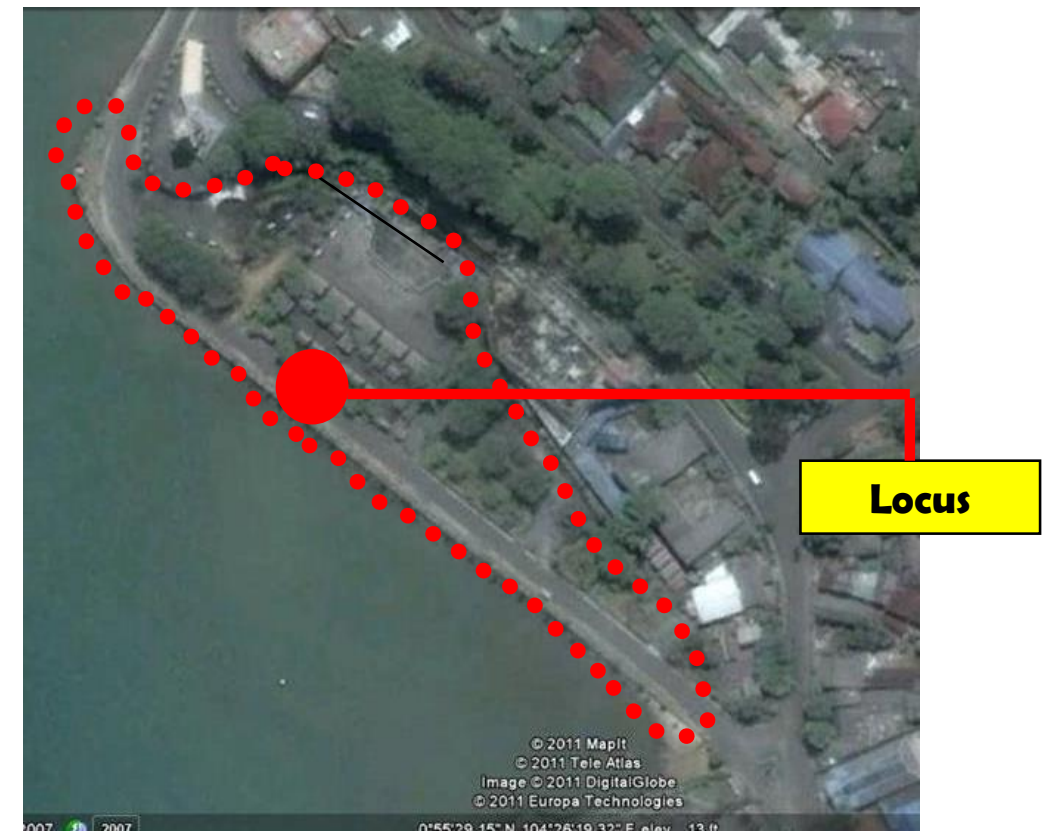

Picture. 3-1 : Delineation Map of the Research Location

Source : Google Earth

\subsubsection{Focus}

The research "The relation between condition open space at public activities happened case study on open space public seaside city tanjungpinang "will be focused on the relationship of characteristic and open space.

\subsection{Research Items}

Here are the research items as the observation objects :

1. The subject of open space.

2. Activity in the open space.

3. Lay Out of open space.

4. Element of open space

\subsection{Stage of Research}

Table, 3-1: Stage of Research

Source : Analyze

\begin{tabular}{|l|l|ll|}
\hline Number & \multicolumn{1}{|c|}{ Stage } & \multicolumn{1}{|c|}{ Activity } \\
\hline Stage 1 & Literature Review & 1. Teoritical Review \\
& & 2. Historical Study \\
\hline Stage 2 & Collecting Data & $\begin{array}{l}\text { 1. } \text { Open space surrounding } \\
\end{array}$ & $\begin{array}{l}\text { 2. } \\
\text { 3. Open space activities }\end{array}$ \\
\hline Stage 3 & Character & 1. Identification of surrounding character \\
& Identification & 2. Identification of activity characteristic of open \\
& & \\
\hline
\end{tabular}




\begin{tabular}{|c|c|c|}
\hline Number & Stage & Activity \\
\hline & & $\begin{array}{l}\text { 3. Identification of relationship between activity and } \\
\text { open space }\end{array}$ \\
\hline Stage 4 & $\begin{array}{l}\text { Analyze of Open Space } \\
\text { Characteristic }\end{array}$ & $\begin{array}{ll}\text { 1. } & \text { Activity Characteristic } \\
\text { 2. Open Space Characteristic } \\
\text { 3. }\end{array}$ \\
\hline Stage 5 & Result and Discussion & $\begin{array}{ll}\text { 1. } & \text { Result Review } \\
\text { 2. Open Space Review } \\
\text { 3. Review of relationship between activity and open } \\
\text { space }\end{array}$ \\
\hline Stage 6 & $\begin{array}{ll}\text { Conclusion } & \text { and } \\
\text { Recommendation }\end{array}$ & $\begin{array}{l}\text { 1. Conclusion of the form and identity of open space. } \\
\text { 2. Recommend the main design which would be a } \\
\text { guideline of open space. }\end{array}$ \\
\hline
\end{tabular}

\subsection{Partial of Research Area}

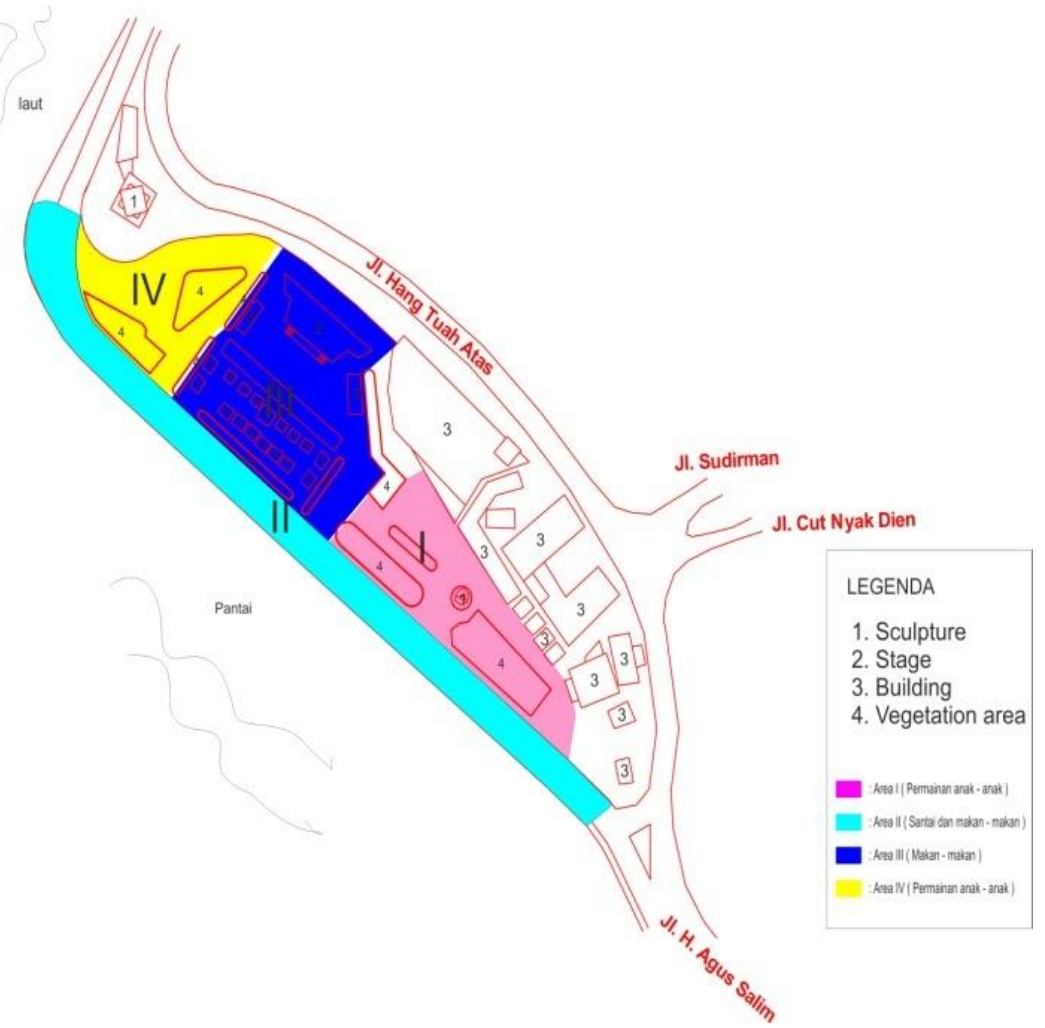

Picture, 4 - 2: Activity area in open space seaside Source : Analyze 
4.1. Result

\section{CHAPTER IV \\ Result and Discussion}

\subsubsection{Activity}

\subsubsection{Area I}
a. Dominated by children.
b. Limited of various of the children playtools.
c. The area is too small.
d. Circulation pattern has not been arranged.

\subsubsection{Area II}
a. Variety of activity is relax activity, food and drink, fishing and sport.
b. There is a difference between major time and holiday.
c. The activity until 02.00 longer than another area.
d. There is some activity which is in seaside, that is fishing.

\subsubsection{Area III}
a. Main activity is food and drink.
b. The activities are done by groups.
c. There are difference activity between major time and holiday.
d. There is no pattern of activity circulation.

\subsubsection{Area IV}
a. Activity are playing, relaxing and selling.
b. The subject of activity are all range of age which is dominated by children.
c. the kind of game that is less various in this location.
d. Circulation pattern cut off the area of activity.

\subsubsection{Open Space Condition}

\subsubsection{Area I}
a. This area is dominated by paving block.
b. Play tools spreaded according to the space of place.
c. Green zone is too wide.
d. There is no facility for parent to wait for their children.
e. Street furniture facility is not so good.

\subsubsection{Area II}
a. There is an additional function like a break water, pedestrian and main road.
b. There is no element for fishing place, sport or sitting place.
c. Placing and function of vegetation is not arranged maximally.
d. Less of street furniture.
e. There is no special room for selling product of food and drink and also sitting place.

\subsubsection{Area III}
a. Pedestrian as internal circulation has not been formed.
b. Building mass facing back to back.
c. Space between vegetations are too small.
d. There is no special lamp for activity lighting.

\subsubsection{Area IV}
a. Form and placing of pedestrian still not clear.
b. Playing ground placed according to space available.
c. Selling place located in circulation path.
d. There is no special lamp for activity lighting.
e. Chair location is not so good. 


\subsection{Discussion}

\subsubsection{Activity}

\subsubsection{Playing}

The location is good for the child's play child's location is a not noisy, relative distance from the noise, as well as having a certain distance from the circulation of motor vehicles that are harmful to the children.

\subsubsection{Food and Drink}

Food and drink is activity where visitors come to enjoy dish provided, this activity is not too demanding object scenery special, but more on atmosphere . Location for the should away from noise and dust resulting from vehicle speed on the road, so healthy environment and food relatively awake. The attraction or object scenery can be added value and increase the quality of the culinary.

\subsubsection{Fishing}

Here in the context of fishing activity a hobby of most of the city people tanjungpinang flood-prone fishing is majority, nor those who are familiar with the sea ; his routine mancing is one form of cultural activities of the city. With fishing they can also enjoy the view from the beautiful about an open space.

\subsubsection{Sport}

Type sporting event that could be doing at the open space is sports which could not membutuhan shape and size and certain specific terms, but sports was sporting that could be doing adjusting to circumstances karateristik open space itself.

\subsubsection{Selling Place}

That becomes main consideration of its placement these activities in the top is a location away from circulation vehicle but relatively close to crowd or be at provide pedestrian as one entity kemenerusan existing activities in the open space.

4.2.1.6. Sit and relax

For the location of relaxed location can be done in all locations, however, to further improve the quality of the activity can choose a place in doing $\%$ u2013 a place that has a view towards certain objects that are owned.

\subsubsection{Open Space}

\subsubsection{Form}

a. Wall

- Stone

Tilted stone is in the open, being the location element ruag massive reaffirms the limits between the open space with other areas, strict limitations would be created as a result of altitude as well as materials that are in use. These limits can be perlembut by using other elements.

The open space is also bordered by a complex of buildings on the location of the City Park Haji Fisabilillah wall\% u2013, so building wall also becomes a part of the creation of the open space specifically as barrier.

- Break Water

In addition to the stone wall building, sloping and open space is also in the limit by break water that separates between the land that became the location of the open space by the sea.

b. Floor / Base

Floor the open space in a form in a certain form by doing pavement, using materials certain to get function element maximal or only done closure by using vegetation as element that can give the impression of soft and natural.

\subsubsection{Attribute}

a. Circulation 
In this open space, the circulation of which there is only the open space allows visitors coming from the direction of Haji Agus Salim Street and Hang Tuah (above) as well as the road Cut Nyak Dien are fused into the path of Hang Tuah (bottom), causing a buildup of point. As well as a pedestrian path pattern formed by the offender in area activities.

b. Building and mass

According to Hamid Shirvani (1985) which need to be noticed in the design guide lines of which is the configuration of the building, including the high scale and expressing also the function it is to maintain harmonization between the buildings in the area that formed.

On the location of open space there is the mendominan, which has a very large scale compared to other buildings. Likewise with the building of a building have a different functions that do not support activities in open spaces.

c. Vegetation

According to the Hakim (1985), to reduce the heat of the Sun on the time of day, parking lot, public spaces and pedestrian paths should have plants peneduh.On site open space Public Seaside Town in southern Malaysia this vegetation is as a function of air filters and Sun, parapet, steering and cover.

d. Street furniture

Street Furniture or often called Utlities of road is one of the elements of the activity at a public space in the form of roads that will strengthen the character of a block design. (Regulation PU No. 6 in 2007)

In open space of Tanjungpinan seaside, the street furniture are :

1. Main Lighting and Road Lighting

As for the lights of the Park has not seen at this location, because the lights are in use as lighting in the Park at night using lamp spot light on certain points that serve as a parking area lighting.

2. Park Bench

Park bench as part of the elements of an open space should give a strong support for those who beraktivitas, especially those who come to the location to rest and saw the sights of existing.

3. Rubbish bin

For in terms of the number of bins is still very lacking, and not spread evenly across the entire site, so visitors and vendors throw litter, due to trash requires a relative distance away.

4. Table and chairs of dining

Desks Dining chairs is a facility for those who enjoy open space while eating drinking at the location of open space, proper placement in the area allocated to consideration, as well as the placement of tables and chairs should also be aligned with the circulation of the internal area of the Group's activities as appropriate.

5. Cart Selling.

Carts selling is the main tool of the traders of food and drink, the location must be appropriate, do not interfere with the circulation, as well as close to location of eating and drinking in the plan in the area of the culinary group.

6. Signage

In this Waterfront open space there are many Billboard, Billboard or bookmarks (signage), however the location as well as its existence is still not right, so its existence is even disturbing sights. 


\section{CHAPTER V \\ Conclusion and Recommendation}

\subsection{Conclusion}

Open space Public Tanjungpinang City Waterfront City Park is a container for a variety of activities for the people of the town in southern Malaysia, pengunjun consists of all circles of society of all ages. A place for locals to sit leisurely while you eat and drink, play, fishing, exercising up to find accessories Activities starting from 06.00 a.m. to 2 p.m. in the morning early hours.

Public open space a seaside Town in southern Malaysia can be access from the road, Jalan Hang Tuah Haji Agus Salim and Jalan Kartini. Building\% u2013 buildings on site open space serves as a container for culinary activities, with a variety of children's games. Trees and vegetation mostly serves as a parapet (barrier) as well as peneduh, steering, air filters and noise as well as land covering. The lights are lights at location still dominated light lamp spot light and the light street lighting lamps who also serves as information activities. Lawn chairs and trash cans spread unevenly across each section location.

Activities conducted in the open space Public Waterfront lot on doing on space\% u2013 are available, but not made specifically according to the character of their respective activities. The circulation formed yet form a pattern of movement that connects every activity.

\subsection{Recommendation}

\subsubsection{Activity}

- Activity in open space a seaside Town in southern Malaysia must preserve.

- Necessary addition of time of activity, especially in the day holidays

- Determines the location of the Group's activities can be done by considering the characters character and needs of the possessed by each activity.

\subsubsection{Open Space}

\subsubsection{Open Space Form}

\subsection{Barrier}

- Sloping stone Being that serves as the dividing line should be softer.

- Break water that becomes parapet with the sea also need in disguise and become space consume.

5.2.2.1.2. Floor / Base

- The existence of paving blocks must be reduced as land cover.

- The addition of the elements rumput as ground cover will give the impression of

5.2.2.2. Attribute natural on open space

\subsection{Circulation}

- Existence of vehicle circulation should be preserved.

- Shapes and patterns of the pedestrian space activities has to inter-relate in the return based on a pattern of movement that occurred.

- Parking vehicles on the street remains the preserve but keep in nomenclature by providing clear guidelines on parking space. 
5.2.2.2. Building and Mass

- Layout and orientation of a building should be changed.

- Layout as well as the location of a gaming device children need to be reset in the right location.

5.2.2.2.3. Vegetation

- Reduction of vegetation on a certain place where\% u2013 are groupings of vegetation.

- Form lay out the vegetation corresponds to the shape of the space activities of the space which is formed, in accordance with existing function.

\subsection{Street Furniture}

a. Lighting

- Still required lights lamp light lighting for the Park and activities that take place.

- Lights need Light in planning in accordance with the Group's activities and in particular patterns, shapes with shapes and colors as the penegas identity function space.

b. Park Bench

- Lawn chairs need to be doing the addition as well as distribution in the location location activities.

c. Rubbish bin

- Trash must be doing the addition as well as distribution in the location location activities.

d. Dining table and chair

- Table seats need to be reorganized, lay out a form directed at a particular object so having clear orientation.

- Need provided space for the location of the table seats are on the sidewalk.

e. Selling Cart

- Cart sellers need to be reset either location, shape and size.

- Placed in a particular location so as not to interfere with the activity of another.

\subsubsection{Theme and Image}

In addition to the above recommendations, a public open spaces can be said both among other things if you have a theme and image.

5.2.3.1. Theme

Many visitors juvenility with various activities, and variety of food of a city tanjungpinang that offer, can be attractive in design theme of this open space.

5.2.3.2. Image

All activities with characteristics that exist in open space, as well as the atmosphere of the layout of open space located at the edge of the sea and the landscape, which became the location of the interaction, is the image of an open space Public Tanjungpinang City Waterfront. 